\title{
Compositional dependence of epitaxial Tin+1SiCn MAX-phase thin films grown from a Ti3SiC2 compound target
}

Martin Magnuson, Lina Tengdelius, Grzegorz Greczynski, Fredrik Eriksson, J ens J ensen, J un Lu, Mattias Samuelsson, Per Eklund, Lars Hultman and Hans Högberg

The self-archived postprint version of this journal article is available at Linköping University Institutional Repository (DiVA):

http:// urn.kb.se/ resolve?urn=urn:nbn:se:liu:diva-154004

N.B.: When citing this work, cite the original publication.

Magnuson, M., Tengdelius, L., Greczynski, G., Eriksson, F., J ensen, J., Lu, J., Samuelsson, M., Eklund, P., Hultman, L., Högberg, H., (2019), Compositional dependence of epitaxial Tin+1SiCn MAX-phase thin films grown from a Ti3SiC2 compound target, J ournal of Vacuum Science \& Technology. A.

Vacuum, Surfaces, and Films, 37(2), 021506. https:/ / doi.org/ 10.1116/ 1.5065468

Original publication available at:

https:// doi.org/ 10.1116/1.5065468

Copyright: AIP Publishing

http:// www.aip.org/ 


\title{
Compositional dependence of epitaxial $\mathrm{Ti}_{n+1} \mathrm{SiC}_{\mathrm{n}}$ MAX-phase thin films grown from a $\mathrm{Ti}_{3} \mathrm{SiC}_{2}$ compound target
}

\author{
Martin Magnuson, ${ }^{a}{ }^{2}$ Lina Tengdelius, Grzegorz Greczynski, Fredrik Eriksson, Jens Jensen, \\ Jun Lu, Mattias Samuelsson, Per Eklund, Lars Hultman, and Hans Högberg \\ Thin Film Physics Division, Department of Physics, Chemistry, and Biology (IFM), Linköping University, \\ SE-581 83 Linköping, Sweden
}

(Received 10 October 2018; accepted 2 January 2019; published 17 January 2019)

\begin{abstract}
The authors investigate sputtering of a $\mathrm{Ti}_{3} \mathrm{SiC}_{2}$ compound target at temperatures ranging from $\mathrm{RT}$ (no applied external heating) to $970{ }^{\circ} \mathrm{C}$ as well as the influence of the sputtering power at $850{ }^{\circ} \mathrm{C}$ for the deposition of $\mathrm{Ti}_{3} \mathrm{SiC}_{2}$ films on $\mathrm{Al}_{2} \mathrm{O}_{3}(0001)$ substrates. Elemental composition obtained from time-of-flight energy elastic recoil detection analysis shows an excess of carbon in all films, which is explained by differences in the angular distribution between $\mathrm{C}, \mathrm{Si}$, and $\mathrm{Ti}$, where $\mathrm{C}$ scatters the least during sputtering. The oxygen content is 2.6 at. \% in the film deposited at RT and decreases with increasing deposition temperature, showing that higher temperatures favor high purity films. Chemical bonding analysis by x-ray photoelectron spectroscopy shows $\mathrm{C}-\mathrm{Ti}$ and $\mathrm{Si}-\mathrm{C}$ bonding in the $\mathrm{Ti}_{3} \mathrm{SiC}_{2}$ films and $\mathrm{Si}-\mathrm{Si}$ bonding in the $\mathrm{Ti}_{3} \mathrm{SiC}_{2}$ compound target. $\mathrm{X}$-ray diffraction reveals that the phases $\mathrm{Ti}_{3} \mathrm{SiC}_{2}, \mathrm{Ti}_{4} \mathrm{SiC}_{3}$, and $\mathrm{Ti}_{7} \mathrm{Si}_{2} \mathrm{C}_{5}$ can be deposited from a $\mathrm{Ti}_{3} \mathrm{SiC}_{2}$ compound target at substrate temperatures above $850{ }^{\circ} \mathrm{C}$ and with the growth of $\mathrm{TiC}$ and the Nowotny phase $\mathrm{Ti}_{5} \mathrm{Si}_{3} \mathrm{C}_{\mathrm{x}}$ at lower temperatures. High-resolution scanning transmission electron microscopy shows epitaxial growth of $\mathrm{Ti}_{3} \mathrm{SiC}_{2}$, $\mathrm{Ti}_{4} \mathrm{SiC}_{3}$, and $\mathrm{Ti}_{7} \mathrm{Si}_{2} \mathrm{C}_{5}$ on $\mathrm{TiC}$ at $970{ }^{\circ} \mathrm{C}$. Four-point probe resistivity measurements give values in the range $\sim 120$ to $\sim 450 \mu \Omega \mathrm{cm}$ and with the lowest values obtained for films containing $\mathrm{Ti}_{3} \mathrm{SiC}_{2}$, $\mathrm{Ti}_{4} \mathrm{SiC}_{3}$, and $\mathrm{Ti}_{7} \mathrm{Si}_{2} \mathrm{C}_{5}$. Published by the AVS. https://doi.org/10.1116/1.5065468
\end{abstract}

\section{INTRODUCTION}

The class of inherently layered carbide and nitride materials known as $\mathrm{M}_{n+1} \mathrm{AX}_{\mathrm{n}}(n=1-3)$ phases ${ }^{1-6}$ have attracted both scientific research and industrial interest because of their unique combination of metallic and ceramic properties. The archetype of this class is $\mathrm{Ti}_{3} \mathrm{SiC}_{2}$, ${ }^{1,7}$ extensively studied as bulk and thin films. ${ }^{8,9}$ For $\mathrm{Ti}_{3} \mathrm{SiC}_{2}$ thin films, early work focused on chemical vapor deposition as reported by Nickl et al. in 1972 (Ref. 10) with several works during the 1980s and 1990s. ${ }^{11-13}$ While CVD has continued to be studied for MAX phases ${ }^{14,15}$ physical vapor deposition and especially sputter deposition is much more established today. There are two main approaches: magnetron sputtering from a $\mathrm{Ti}_{3} \mathrm{SiC}_{2}$ compound or other composite target, and growth from elemental targets $(\mathrm{Ti}, \mathrm{Si}$, and graphite, or in some of the early work together with $\mathrm{C}_{60}$ evaporation). ${ }^{16}$ Epitaxial growth of $\mathrm{Ti}_{3} \mathrm{SiC}_{2}$ on $\mathrm{MgO}(111)$ substrates was demonstrated at substrate temperatures in the range $900-1050{ }^{\circ} \mathrm{C}$. For fundamental research and exploration of the Ti-Si-C system, sputtering from individual sources became the preferred synthesis route. ${ }^{17,18}$ In 2002, the $\mathrm{Ti}_{4} \mathrm{SiC}_{3}$ phase had been theoretically predicted, ${ }^{19}$ and this sputtering methodology enabled the discovery of the $\mathrm{Ti}_{4} \mathrm{SiC}_{3}$ phase as well as two intergrown phases in the form of $\mathrm{Ti}_{5} \mathrm{Si}_{2} \mathrm{C}_{3}$ and $\mathrm{Ti}_{7} \mathrm{Si}_{2} \mathrm{C}_{5}$, with alternating " 211 " and " 312 " or "312" and "413" layers, respectively. ${ }^{17}$ In 2011, Scabarozi et al. showed that it is possible to deposit almost phase pure and epitaxial $\mathrm{Ti}_{7} \mathrm{Si}_{2} \mathrm{C}_{5}$ by reactive sputtering, ${ }^{20}$ and recently the $\mathrm{Ti}_{4} \mathrm{SiC}_{3}$ phase has been demonstrated in bulk. ${ }^{21-23}$

\footnotetext{
${ }^{a)}$ Electronic mail: martin.magnuson@liu.se
}

For industrial applications, growth from elemental sputter sources poses limitations for a simple, repeatable and scalable process, shifting the attention back to compound targets. Depositions from a $\mathrm{Ti}_{3} \mathrm{SiC}_{2}$ compound target using substrate temperatures $\leq 300{ }^{\circ} \mathrm{C}$ (Ref. 24) typically result in growth of nanocomposite thin films of nanocrystalline (nc)-TiC/ amorphous (a)-SiC. Another study by Eklund et al. ${ }^{25}$ at higher deposition temperatures showed that epitaxial $\mathrm{Ti}_{3} \mathrm{SiC}_{2}$ films containing $\mathrm{Ti}_{4} \mathrm{SiC}_{3}$ and $\mathrm{Ti}_{7} \mathrm{Si}_{2} \mathrm{C}_{5}$ phases could be co-sputtered from a $\mathrm{Ti}_{3} \mathrm{SiC}_{2}$ compound target together with a Ti target on a $\mathrm{TiC}(111)$ seed layer on $\mathrm{Al}_{2} \mathrm{O}_{3}(0001)$ substrates at $850^{\circ} \mathrm{C}$.

Balzer and Fenker $^{26}$ applied high power impulse magnetron sputtering (HiPIMS) to deposit films of 3Ti:Si:2C stoichiometry from a $\mathrm{Ti}_{3} \mathrm{SiC}_{2}$ target without substrate heating. Growth from HiPIMS was also used by Alami et $a .^{27}$ at a substrate temperature of $680^{\circ} \mathrm{C}$, which resulted in the deposition of crystalline $\mathrm{TiC}$ or a phase mixture of the Nowotny $\mathrm{Ti}_{5} \mathrm{Si}_{3} \mathrm{C}_{\mathrm{x}}$-phase and $\mathrm{TiC}$ depending on the inclination angle of the sputtered material. The Nowotny phase $\mathrm{Ti}_{5} \mathrm{Si}_{3} \mathrm{C}_{\mathrm{x}}$ can be considered as a solid solution of carbon in the silicide $\mathrm{Ti}_{5} \mathrm{Si}_{3} .{ }^{28,29}$

The results presented above show that growth of $\mathrm{Ti}_{3} \mathrm{SiC}_{2}$ from a $\mathrm{Ti}_{3} \mathrm{SiC}_{2}$ compound target is not straightforward, but highly dependent on the choice of deposition parameters. The coating composition depends on gas-phase scattering processes and differences in angular and energy distributions of sputtered atoms, which is to be expected given the difference in masses between $\mathrm{Ti}, \mathrm{Si}$, and $\mathrm{C}^{25}$ In contrast, backscattering of Ar neutrals is not an operative effect, as it is for heavy elements, see, e.g., Refs. 30-32, for sputtering of 


\section{Compositional dependence of epitaxial Tin+1SiCn MAX-phase thin films grown from a Ti3SiC2 compound target}

Martin Magnuson, Lina Tengdelius, Grzegorz Greczynski, Fredrik Eriksson, J ens J ensen, J un Lu, Mattias Samuelsson, Per Eklund, Lars Hultman and Hans Högberg

The self-archived postprint version of this journal article is available at Linköping University Institutional Repository (DiVA):

http:// urn.kb.se/ resolve?urn=urn:nbn:se:liu:diva-154004

N.B.: When citing this work, cite the original publication.

Magnuson, M., Tengdelius, L., Greczynski, G., Eriksson, F., J ensen, J., Lu, J., Samuelsson, M., Eklund, P., Hultman, L., Högberg, H., (2019), Compositional dependence of epitaxial Tin+1SiCn MAX-phase thin films grown from a Ti3SiC2 compound target, J ournal of Vacuum Science \& Technology. A.

Vacuum, Surfaces, and Films, 37(2), 021506. https:/ / doi.org/ 10.1116/ 1.5065468

Original publication available at:

https:// doi.org/ 10.1116/1.5065468

Copyright: AIP Publishing

http:// www.aip.org/ 
WTi. For Ti-B films, Neidhardt et al. ${ }^{33}$ concluded that the stoichiometry of the Ti-B films is highly dependent on the pressure-distance product.

In the present study, we apply a target-to-substrate distance of $7 \mathrm{~cm}$ and with the sputter target directly facing the substrate surface, substrate temperatures up to $1000^{\circ} \mathrm{C}$, and an argon pressure of 4 mTorr to deposit $\mathrm{Ti}_{3} \mathrm{SiC}_{2}$ films on $\mathrm{Al}_{2} \mathrm{O}_{3}(0001)$ substrates from a $\mathrm{Ti}_{3} \mathrm{SiC}_{2}$ compound target. Films consisting of $\mathrm{Ti}_{3} \mathrm{SiC}_{2}, \mathrm{Ti}_{4} \mathrm{SiC}_{3}$, and $\mathrm{Ti}_{7} \mathrm{Si}_{2} \mathrm{C}_{5}$ MAX phases were grown.

\section{EXPERIMENTAL CONDITIONS}

\section{A. Deposition}

The films were deposited by direct-current magnetron sputtering from a 3-in. circular $\mathrm{Ti}_{3} \mathrm{SiC}_{2}$ compound target from Kanthal, Sweden, in an ultrahigh vacuum (UHV) system (base pressure of $\sim 10^{-6} \mathrm{~Pa}$ ) with the substrate positioned directly in line-of-sight above the magnetron at a distance of $7 \mathrm{~cm}$. In all depositions, the argon (99.9997\%) pressure was kept constant at $0.53 \mathrm{~Pa}$ and growth was carried out at a floating potential corresponding to $\sim-25 \mathrm{~V}$. To minimize the possibility of crack formation in the target, the sputtering power was ramped to the desired power during at least $240 \mathrm{~s}$. To avoid stray coating on the substrates, we used a shutter that completely covered the magnetron. We investigated the growth conditions at substrate temperatures ranging from no applied external heating (RT) to $970{ }^{\circ} \mathrm{C}$, the highest possible temperature for the applied substrate heater, using a sputtering power of $300 \mathrm{~W}$ that corresponds to a sputtering current of $\sim 660 \mathrm{~mA}$ as seen from a discharge voltage of $\sim 450 \mathrm{~V}$ and for a deposition time of $300 \mathrm{~s}$. The film thickness determined at a sputtering power of $300 \mathrm{~W}$ was $200 \mathrm{~nm}$ corresponding to a growth rate of $40 \mathrm{~nm} / \mathrm{min}$ at a deposition time of $300 \mathrm{~s}(5 \mathrm{~min})$. At $850^{\circ} \mathrm{C}$, we studied the influence of sputtering power by applying $50,100,150,200$, and $250 \mathrm{~W}$ to the target, which resulted in sputtering currents of $\sim 130, \sim 240, \sim 350$, $\sim 450$, and $\sim 560 \mathrm{~mA}$, respectively. For the synthesis of films with similar thicknesses at lower sputter powers than $300 \mathrm{~W}$, we applied longer deposition times of 1576, 811, 560, 432, and $352 \mathrm{~s}$ in order to achieve a constant sputter current-time product at $50,100,150,200$, and $250 \mathrm{~W}$, respectively. As substrates, we used pieces cut from an $\mathrm{Al}_{2} \mathrm{O}_{3}(0001)$ wafer with the size $1.25 \times 1.25 \mathrm{~cm}$ to study epitaxial growth and two $1.25 \times 1.25$ cm pieces of $1000 \AA \mathrm{SiO}_{2} / \mathrm{Si}(100)$ in each run. The sapphire substrate was mounted in the middle of the substrate holder and with the oxidized silicon substrates in positions on each side adjacent to the central position without substrate rotation. The latter was used for thickness measurements only. Prior to deposition, the substrates were degreased in 5 min sequential ultrasonic baths of trichloroethylene, acetone, and isopropanol, and blown dry with pure nitrogen. This was followed by an in situ heat treatment for $1 \mathrm{~h}$ at $900{ }^{\circ} \mathrm{C}$ in the growth chamber before adjusting the temperature to the desired value.

\section{B. Thin film characterization}

The films deposited on $\mathrm{Al}_{2} \mathrm{O}_{3}(0001)$ and the $\mathrm{Ti}_{3} \mathrm{SiC}_{2}$ compound target were investigated by $\mathrm{x}$-ray photoelectron spectroscopy (XPS) to determine the chemical bonding structure as well as the elemental composition, using an AXIS Ultra-DLD instrument from Kratos Analytical employing monochromatic $\mathrm{Al} K \alpha$ radiation. In order to compensate for charge-up effects due to the insulating properties of the $\mathrm{Al}_{2} \mathrm{O}_{3}(0001)$ substrate, the samples were irradiated by low energy electrons from a flood-gun during the entire analysis. To remove adsorbed contaminants following exposure to the air, the samples were sputter-cleaned for $180 \mathrm{~s}$ with $4 \mathrm{keV} \mathrm{Ar}^{+}$ions incident at a take-off angle of $20^{\circ}$. In the case of the $\mathrm{Ti}_{3} \mathrm{SiC}_{2}$ compound target, a longer etching time of $720 \mathrm{~s}$ was used to account for the significantly rougher surface. The binding energy (BE) scale was calibrated by setting the Ti $2 p_{3 / 2}$ peak to $454.7 \mathrm{eV}$ corresponding to Ti-C bonding in the analyzed $\mathrm{Ti}_{3} \mathrm{SiC}_{2}$ compound target. ${ }^{34,35}$ Quantitative analysis was performed using the CASA XPS software. ${ }^{36}$

The qualitative and quantitative analyses performed by XPS were corroborated by time-of-flight energy elastic recoil detection analysis (ToF-E ERDA) of the films deposited on $\mathrm{Al}_{2} \mathrm{O}_{3}(0001)$. The measurements were carried out with a $36 \mathrm{MeV}{ }^{127} \mathrm{I}^{8+}$ ion beam using the setup at Uppsala University. ${ }^{37,38}$ The incident angle of primary ions and exit angle of recoils were both $67.5^{\circ}$ to the sample surface normal giving a recoil angle of $45^{\circ}$. The measured ToF-E ERDA spectra were converted into relative atomic concentration profiles using the conTEs code. ${ }^{39}$

The phase composition in the films and the sputtering target were assessed by x-ray diffraction (XRD), conducting $\theta / 2 \theta$ scans in a Philips powder diffractometer (PW 1820) with $\mathrm{Cu} K \alpha$ radiation at $40 \mathrm{kV}$ and $40 \mathrm{~mA}$. For the applied $\mathrm{Ti}_{3} \mathrm{SiC}_{2}$ target material, the mass fraction of each phase was determined using reference intensity ratio values and scale factors using the HIGHSCORE software from Panalytical ${ }^{40}$ and the ICDD PDF database.

The cross-sectional transmission electron microscopy (HRTEM) specimens were prepared by gluing the film face to face to form a sandwich specimen, polishing the specimen from both sides to $50 \mu \mathrm{m}$, followed by ion milling until electron transparency. The details of cross-sectional HRTEM specimen preparation can be found in our previous work. ${ }^{41}$ Z-contrast scanning electron microscopy (STEM) together with $\mathrm{x}$-ray energy dispersive spectroscopy (EDX) was carried out in a double Cs-corrected FEI Titan3 60300 operated at $300 \mathrm{kV}$ and equipped with a Super-X EDX detector.

The thicknesses of the films deposited on $1000 \AA \mathrm{SiO}_{2} /$ $\mathrm{Si}(100)$ substrates were investigated using cross-sectional scanning electron microscopy (SEM, LEO 1550 Gemini) and with images collected at an acceleration voltage of $10 \mathrm{kV}$.

Room temperature four-point probe measurements were performed on films synthesized on $\mathrm{Al}_{2} \mathrm{O}_{3}(0001)$ with an Auto map system Model 280C from Four Dimensions, Inc. The in-plane resistivity was then calculated by multiplying the obtained sheet resistance with the film thickness obtained by SEM imaging of cross sections of films deposited on the $1000 \AA \mathrm{SiO}_{2} / \mathrm{Si}(100)$ substrates. 


\section{RESULTS AND DISCUSSION}

Figure 1 is a plot of elemental compositions obtained from ERDA measurements for Ti-Si-C films deposited on $\mathrm{Al}_{2} \mathrm{O}_{3}(0001)$ substrates at temperatures [Fig. 1(a), left] of RT, 300, 500, 600, 700, 800, 850, 900, and $970{ }^{\circ} \mathrm{C}$ and [Fig. 1(b), right] at sputtering powers of 50, 100, 150, 200, 250 , and $300 \mathrm{~W}$. The ideal composition of the $\mathrm{Ti}_{3} \mathrm{SiC}_{2}$ compound target with 50 at. $\% \mathrm{Ti}, 16.7$ at. $\% \mathrm{Si}$, and 33.3 at. \% $\mathrm{C}$ is indicated as dotted lines. The figure shows that all investigated films exhibit compositions that differ from that of the $\mathrm{Ti}_{3} \mathrm{SiC}_{2}$ compound target, i.e., ideally 50 at. $\% \mathrm{Ti}$, 16.7 at. $\% \mathrm{Si}$, and 33.3 at. $\% \mathrm{C}$, as indicated by the dotted lines for $\mathrm{Ti}, \mathrm{Si}$, and $\mathrm{C}$. The ERDA results show that all films exhibit a $\mathrm{C}$ content higher than that of the $\mathrm{Ti}_{3} \mathrm{SiC}_{2}$ compound target, with 38.5 at. $\%$ in the film deposited at RT and 47.3 at. \% when applying $50 \mathrm{~W}$ sputtering power and at a substrate temperature of $850{ }^{\circ} \mathrm{C}$. A higher carbon content than 33 at. \% agrees with studies by Eklund et al. for films deposited from a $\mathrm{Ti}_{3} \mathrm{SiC}_{2}$ compound target at 4 mTorr and $300{ }^{\circ} \mathrm{C}$ (Ref. 24) as well as $850{ }^{\circ} \mathrm{C} .{ }^{25}$ Alami et al. $^{27}$ reported carbon deficient films grown with HiPIMS at $90^{\circ}$ inclination angle for the growth flux.

The reason for the excess carbon content is that the angular distribution of the species from the target differs for the different elements, with $\mathrm{C}$ being much more focused along the $z$ axis and the heavier elements (Ti, Si) spread broader. ${ }^{25}$ This played a critical role in the present geometry with the substrates mounted in the center of the sample holder.

Furthermore, for all the investigated films, the Si content is in the region $\sim 15-17$ at. $\%$, i.e., close to that of an ideal target composition. The $\mathrm{O}$ content is low and decreases as the substrate temperature increases, seen from $\sim 2.6$ at. $\%$ in the film deposited at RT and moving towards the detection limit of ERDA at $970{ }^{\circ} \mathrm{C}$. As the growth was carried out at UHV conditions, we suggest that oxygen originates from the $\mathrm{Ti}_{3} \mathrm{SiC}_{2}$ compound target as XPS quantitative analysis shows $\sim 8$ at. $\% \mathrm{O}$ in the bulk of the material. Schneider et $a l^{42}$ also suggested the sputtering target as a source of oxygen during sputtering of $\mathrm{Cr}_{2} \mathrm{AlC}$ films from a $\mathrm{Cr}_{2} \mathrm{AlC}$ compound target with reported values of $\sim 3$ at. $\%$ at $650{ }^{\circ} \mathrm{C}$.

Figures 2(a) and 2(b) show XPS measurements at the Ti $2 p_{3 / 2,1 / 2}$, C $1 s$, Si $2 s$, and Si $2 p$ edges of Ti-Si-C films deposited with a sputtering power of 50 or $300 \mathrm{~W}$ at $850{ }^{\circ} \mathrm{C}$ or at $\mathrm{RT}$ at a sputtering power of $300 \mathrm{~W}$, in comparison to the $\mathrm{Ti}_{3} \mathrm{SiC}_{2}$ compound target. The bulk material has photoelectron peaks at 454.7, 460.6, 282.0, 150.4, and $99.1 \mathrm{eV}$ binding energies, respectively. These values are in good agreement with XPS measurements of a reactively hotpressed $\mathrm{Ti}_{3} \mathrm{SiC}_{2}$ sample by Stoltz et al. ${ }^{43}$ with $454.74 \mathrm{eV}$ for Ti $2 p_{3 / 2}, 460.8 \mathrm{eV}$ for Ti $2 p_{1 / 2}, 281.83 \mathrm{eV}$ for C $1 s, 98.91 \mathrm{eV}$ for $\mathrm{Si} 2 p_{3 / 2}$, and $99.52 \mathrm{eV}$ for Si $2 p_{1 / 2}$.

As the investigated films were deposited on $\mathrm{Al}_{2} \mathrm{O}_{3}(0001)$ substrates, charge compensation was necessary by means of setting the Ti $2 p_{3 / 2}$ peak in Fig. 2(a) (top panel) to $454.7 \mathrm{eV}$, i.e., the same binding energy as recorded for the bulk $\mathrm{Ti}_{3} \mathrm{SiC}_{2}$ compound target and corresponding to $\mathrm{Ti}-\mathrm{C}$ bonding ${ }^{35,44}$ marked with a dotted line. From the Ti $2 p_{3 / 2,1 / 2}$ peak structures, we observe that the film XPS peaks align to those of the $\mathrm{Ti}_{3} \mathrm{SiC}_{2}$ compound target, where all the investigated samples have a spin-orbit splitting of $5.9 \mathrm{eV}$. The energy calibration of the $\mathrm{Ti} 2 p_{3 / 2,1 / 2}$ peaks agrees with the study by Eklund et al., ${ }^{34}$ investigating epitaxial TiC(111) and $\mathrm{Ti}_{3} \mathrm{SiC}_{2}(0001)$ films, comparing the chemical bonding structure to nc-TiC/a-SiC films.

The bottom panel in Fig. 2(a) shows C $1 s$ photoelectron peaks of the films deposited with 50 and $300 \mathrm{~W}$ sputtering power that are located at a lower binding energy of $281.7 \mathrm{eV}$ compared to the $\mathrm{Ti}_{3} \mathrm{SiC}_{2}$ compound target and the RT film which both show $282.0 \mathrm{eV}$. The C-Ti peak at $281.7 \mathrm{eV}$ coincides with values between 281.6 and $281.8 \mathrm{eV}$ (Refs. 35, 45 and 46) as indicated by a dotted vertical line in Fig. 2(a), bottom panel. When compared to the $\mathrm{Ti}_{3} \mathrm{SiC}_{2}$ compound target, the $\mathrm{C} 1 s$ peaks of the films have more pronounced tails toward higher binding energy, with literature values of $\mathrm{C}-\mathrm{Si}$ bonding at $282.5 \mathrm{eV},{ }^{47} \mathrm{C}-\mathrm{Ti}^{*}$ at $283.0 \mathrm{eV},{ }^{48}$ as indicated by a dotted vertical line in Fig. 2(a), bottom panel.
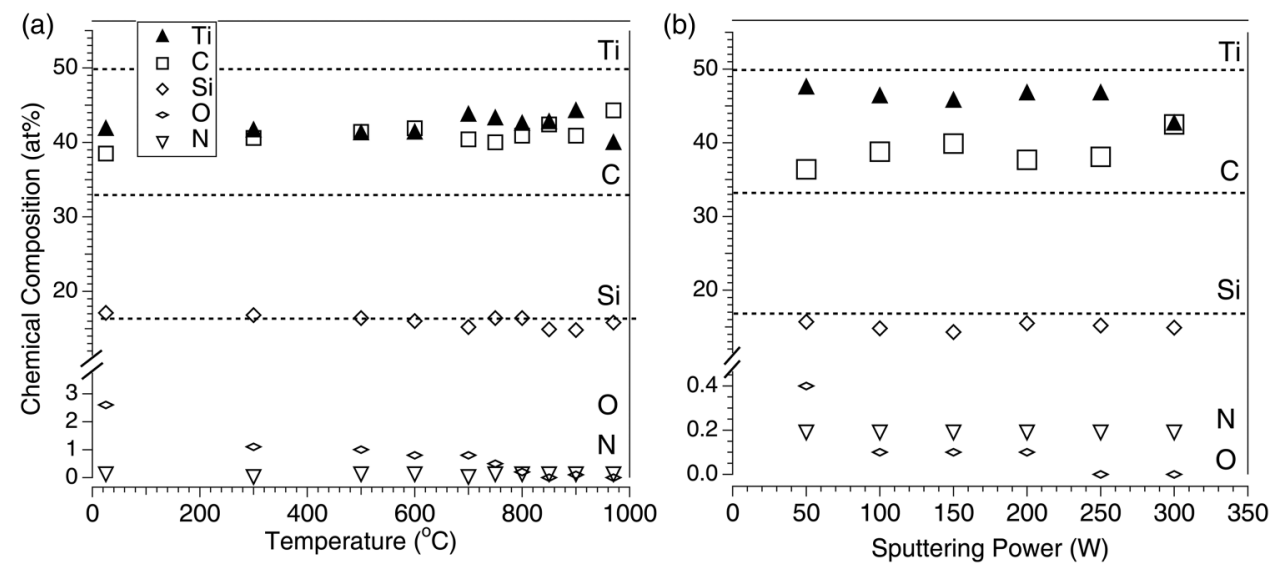

FIG. 1. ERDA compositions for Ti-Si-C films deposited on $\mathrm{Al}_{2} \mathrm{O}_{3}(0001)$ substrates at temperatures [(a), left] of RT, 300, 500, 600, 700, 800, 850, 900, and $970{ }^{\circ} \mathrm{C}$ and [(b), right] at sputtering powers of $50,100,150,200,250$, and $300 \mathrm{~W}$. The ideal composition of the $\mathrm{Ti}_{3} \mathrm{SiC}_{2}$ compound target with 50 at. $\%$ Ti, 16.7 at. $\% \mathrm{Si}$, and 33.3 at. $\% \mathrm{C}$ is indicated as dotted lines. 

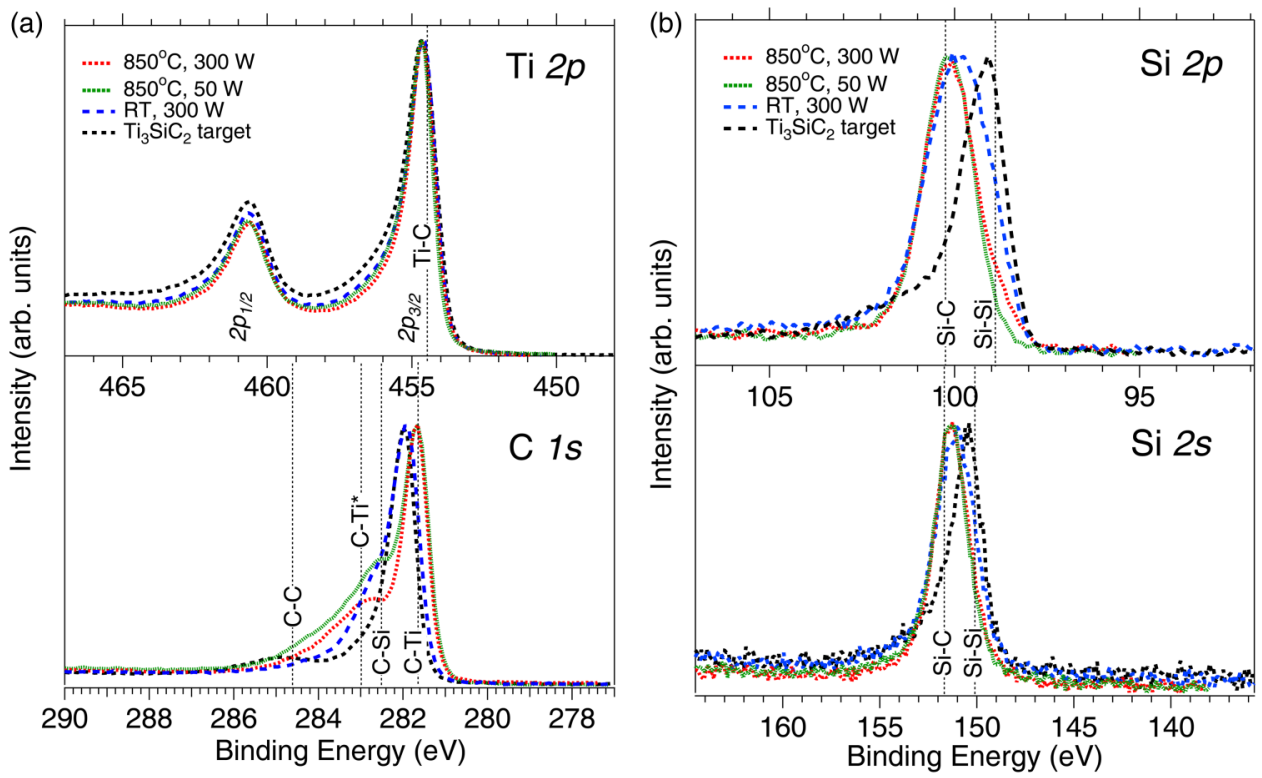

FIG. 2. XPS Ti $2 p, \mathrm{C} 1 s, \mathrm{Si} 2 s$, and $\mathrm{Si} 2 p$ spectra recorded from the $\mathrm{Ti}_{3} \mathrm{SiC}_{2}$ compound target after $720 \mathrm{~s}$ of sputter-cleaning and Ti-Si-C films deposited on $\mathrm{Al}_{2} \mathrm{O}_{3}(0001)$ substrates at temperatures of $850^{\circ} \mathrm{C}$ and with sputtering powers of 50 or $300 \mathrm{~W}$, or at $\mathrm{RT}$ and a sputtering power of $50 \mathrm{~W}$ following $180 \mathrm{~s}$ of sputter-cleaning. Literature binding energies for Ti-C (Ref. 44), C-Ti (Ref. 35), C-Si (Ref. 47), C-Ti* (Ref. 48), C-C (Ref. 48), Si-C (Ref. 47), and Si-Si (Ref. 43) are indicated by the vertical dotted lines.

A closer inspection of the intensities in the tails of the $\mathrm{C} 1 \mathrm{~s}$ data suggests more pronounced $\mathrm{C}-\mathrm{Si}$ bonding in the film deposited at $850^{\circ} \mathrm{C}$ with $50 \mathrm{~W}$, the film with the highest carbon content of 47.3 at. \%, whereas the $\mathrm{C}-\mathrm{Ti} *$ contribution appears to increase when increasing the sputtering power to $300 \mathrm{~W}$. These observations are correlated with a possible interface state or phase contribution as previously observed as a feature due to charge transfer, denoted $\mathrm{C}_{-} \mathrm{Ti}^{*}$ in $\mathrm{C} 1 \mathrm{~s}$ XPS spectra from nanocrystalline-TiC in an amorphous $\mathrm{C}$ matrix $^{48,49}$ also interpreted as sputtering damage. ${ }^{50}$ From XPS, the tail from the film deposited at RT and $300 \mathrm{~W}$ sputtering power shows the contribution from both $\mathrm{C}-\mathrm{Si}$ and $\mathrm{C}-\mathrm{Ti}^{*}$ in this film with a $\mathrm{C}$ content of 38.5 at. \%. In addition, there is a signature of $\mathrm{C}-\mathrm{C}$ bonds as indicated by a dotted vertical line in Fig. 2(a), bottom panel, at $284.6 \mathrm{eV}^{48}$ most pronounced for the $\mathrm{Ti}_{3} \mathrm{SiC}_{2}$ target.

In Fig. 2(b) (top panel), the binding energies of the Si $2 p$ peaks are higher in the films seen from $99.85 \mathrm{eV}$ for the film deposited with $300 \mathrm{~W}$ sputtering power at RT condition, $100.15 \mathrm{eV}$ for the film deposited with $50 \mathrm{~W}$ sputtering power at $850{ }^{\circ} \mathrm{C}$, and $100.15 \mathrm{eV}$ for the film deposited with $300 \mathrm{~W}$ sputtering power at $850{ }^{\circ} \mathrm{C}$ compared to that of the $\mathrm{Ti}_{3} \mathrm{SiC}_{2}$ compound target at $99.1 \mathrm{eV}$.

The Si $2 p$ peaks of the films deposited with 50 and $300 \mathrm{~W}$ sputtering power are close to the reported value of the $\mathrm{Si}-\mathrm{C}$ bonding at $100.3 \mathrm{eV}$ (Ref. 47) [indicated by a dotted vertical line in Fig. 2(b), bottom panel] and $\mathrm{Si}-\mathrm{C}$ bonding is supported by the C $1 s$ XPS region. The film grown without external heating shows a somewhat lower binding energy of $99.9 \mathrm{eV}$, i.e., closer to $\mathrm{Si}-\mathrm{C}$ bonding than $\mathrm{Si}-\mathrm{Si}$ bonding at $98.91 \mathrm{eV}^{43}$

The observations made from the Si $2 p$ peak positions in Fig. 2(b) are consistent with the peak positions of the Si $2 s$ spectra in the bottom panel, i.e., the $\mathrm{Si} 2 s$ binding energies are higher than in the $\mathrm{Ti}_{3} \mathrm{SiC}_{2}$ compound target at $150.4 \mathrm{eV}$ compared to the film peaks at $151.05 \mathrm{eV}$ (RT), $151.35 \mathrm{eV}$ $(50 \mathrm{~W})$, and $151.35 \mathrm{eV}(300 \mathrm{~W})$. For comparison, the literature value for the $\mathrm{Si}-\mathrm{Si}$ bonding is $150.50 \mathrm{eV}$ (Ref. 51) and $151.70 \mathrm{eV}$ for Si-C. ${ }^{52}$

Figure 3 shows an $x$-ray $\theta / 2 \theta$ scan recorded from the $\mathrm{Ti}_{3} \mathrm{SiC}_{2}$ compound target. The diffraction pattern displays all prominent $\mathrm{Ti}_{3} \mathrm{SiC}_{2}$ peaks listed in the reference diffraction pattern, ${ }^{53}$ and where the intensity distribution among the $\mathrm{Ti}_{3} \mathrm{SiC}_{2}$ peaks supports a randomly oriented target material. ${ }^{53}$ $\mathrm{Ti}_{3} \mathrm{SiC}_{2}$ reflections from the reference diffraction pattern are

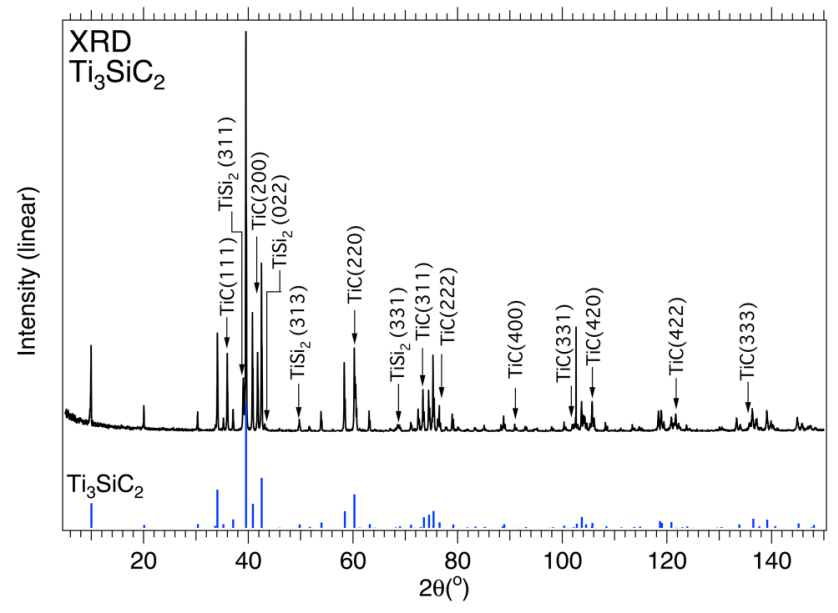

FIG. 3. X-ray $\theta / 2 \theta$ scan recorded from the thin film growth applied $\mathrm{Ti}_{3} \mathrm{SiC}_{2}$ compound target. The arrows indicate reflections from the $\mathrm{TiC}$ and $\mathrm{TiSi}_{2}$ minority phases. The bars below the diffractogram represent peak positions and intensities from $\mathrm{Ti}_{3} \mathrm{SiC}_{2}$ in Ref. 53. 

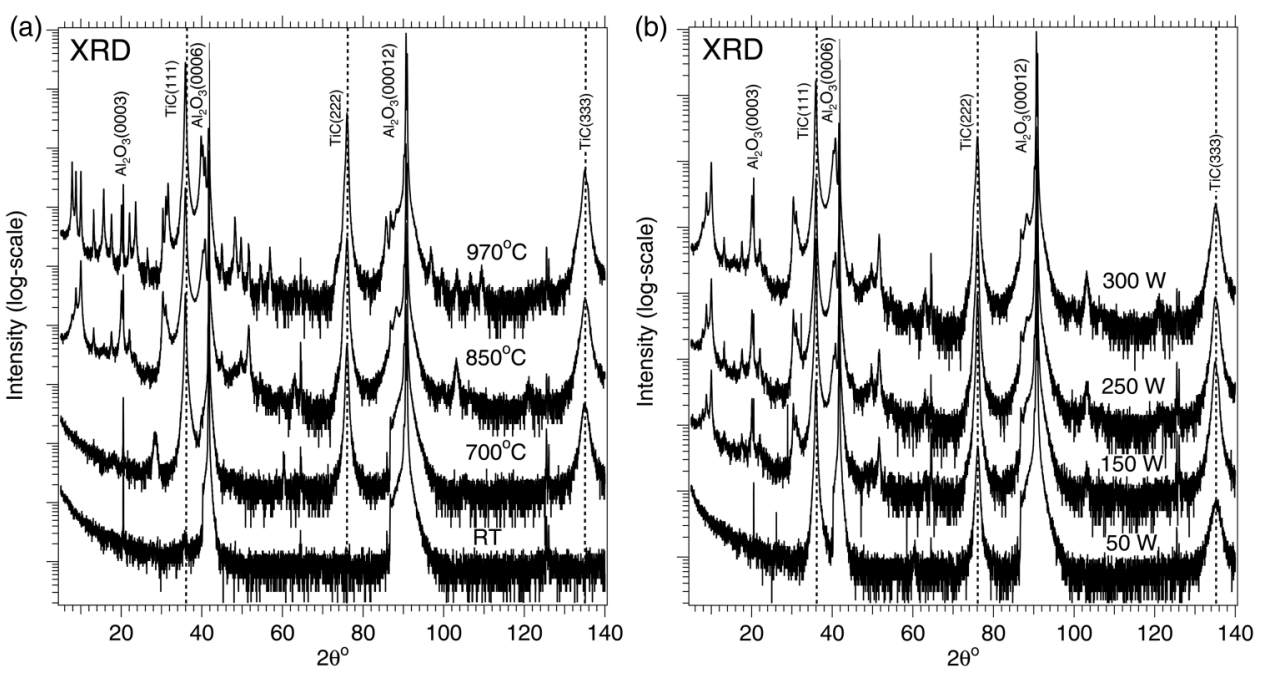

FIG. 4. X-ray $\theta / 2 \theta$ scans from Ti-Si-C films deposited on $\mathrm{Al}_{2} \mathrm{O}_{3}(0001)$ substrates using substrate temperatures of $\mathrm{RT}, 700,850$, and $970{ }^{\circ} \mathrm{C}$ at a sputtering power of $300 \mathrm{~W}$ [(a), left] as well as sputtering powers of 50,150, 250, and $300 \mathrm{~W}[(\mathrm{~b})$, right].

indicated by the vertical bars at the bottom of Fig. 3. In addition, the diffractogram shows clearly visible peaks from $\mathrm{TiC}$ $111,200,220,311,222,400,331,420,422$, and 511/333 seen from increasing $2 \theta$ angles. ${ }^{54}$ Peaks at $2 \theta$ angles of $39.1^{\circ}$, $43.2^{\circ}, 49.7^{\circ}$, and, $68.7^{\circ}$ correspond to the $311,022,313$, and 331 peaks in orthorhombic $\mathrm{TiSi}_{2}$, respectively. ${ }^{55}$ On the other hand, $\mathrm{Ti}_{5} \mathrm{Si}_{3}$ cannot be found in the diffraction pattern. Quantitative XRD analysis revealed that the target material consists of only a $78 \%$ mass fraction of $\mathrm{Ti}_{3} \mathrm{SiC}_{2}$, while $\mathrm{TiC}$ and $\mathrm{TiSi}_{2}$ constitute the remaining $13 \%$ and $9 \%$, respectively. The presence of minority phases has also been observed in other target MAX-phase materials such as $\mathrm{Ti}_{2} \mathrm{AlC}$ (Ref. 56) and $\mathrm{Cr}_{2} \mathrm{AlC},{ }^{42}$ but typically at much lower content $(<5 \%)$. As previously mentioned, quantitative analysis from XPS spectra yielded an $\mathrm{O}$ content of $\sim 7.7$ at. $\%$ and with a bulk composition of 36.6 at. $\% \mathrm{Ti}, 18.7$ at. $\% \mathrm{Si}$, and 37.0 at. $\% \mathrm{C}$, i.e., that is different from the ideal 50 at. $\% \mathrm{Ti}, 16.7$ at. $\% \mathrm{Si}$, and 33.3 at. $\%$ C. It is likely that the properties determined from the sputtering source will affect the possibilities to deposit epitaxial $\mathrm{Ti}_{3} \mathrm{SiC}_{2}$.
Figure 4 shows $\mathrm{x}$-ray $\theta / 2 \theta$ scans of Ti-Si-C films deposited on $\mathrm{Al}_{2} \mathrm{O}_{3}(0001)$ substrates as functions of temperature [Fig. 4(a), left] and power [Fig. 4(b), right]. For growth at $\mathrm{RT}$, the diffraction pattern only displays a weak peak at $2 \theta \approx$ $36^{\circ}$ from $\mathrm{TiC} 111$, and where a potential TiC 200 peak overlaps with the $\mathrm{Al}_{2} \mathrm{O}_{3} 0006$ peak. At 300 and $500{ }^{\circ} \mathrm{C}$, the $\mathrm{TiC}$ 111 peak increases in intensity and $\mathrm{TiC} 220$ and $\mathrm{TiC} 222$ peaks appear at $2 \theta \approx 60.5^{\circ}$ and $2 \theta \approx 76.1^{\circ}$, respectively (not shown). At $700^{\circ} \mathrm{C}$, there are clear peaks from TiC 111, 222, and 333 , indicating oriented growth. ${ }^{57}$ In addition, there is a peak at $2 \theta \approx 30^{\circ}$, corresponding to the Nowotny phase $\mathrm{Ti}_{5} \mathrm{Si}_{3} \mathrm{C}_{\mathrm{x}}$. Emmerlich et al. ${ }^{18}$ reported growth of $\mathrm{Ti}_{5} \mathrm{Si}_{3} \mathrm{C}_{\mathrm{x}}$ at $700{ }^{\circ} \mathrm{C}$ by sputtering from elemental sources, and it has also been deposited by sequential growth by Vishnyakov et al. ${ }^{29}$ At $850^{\circ} \mathrm{C}$, there are peaks at low angles [for clarity, see Fig. 5(a)] that originate from $\mathrm{Ti}_{3} \mathrm{SiC}_{2}, \mathrm{Ti}_{4} \mathrm{SiC}_{3}$, and the intergrown $\mathrm{Ti}_{7} \mathrm{Si}_{2} \mathrm{C}_{5}$ phase. $\mathrm{A} \mathrm{Ti}_{3} \mathrm{SiC}_{2}$ peak of low-intensity and positioned at $2 \theta=10.0^{\circ}$ is visible already at a deposition temperature of $800{ }^{\circ} \mathrm{C}$. Increasing the temperature to $970{ }^{\circ} \mathrm{C}$ results in higher intensities for the peaks from $\mathrm{Ti}_{3} \mathrm{SiC}_{2}$,
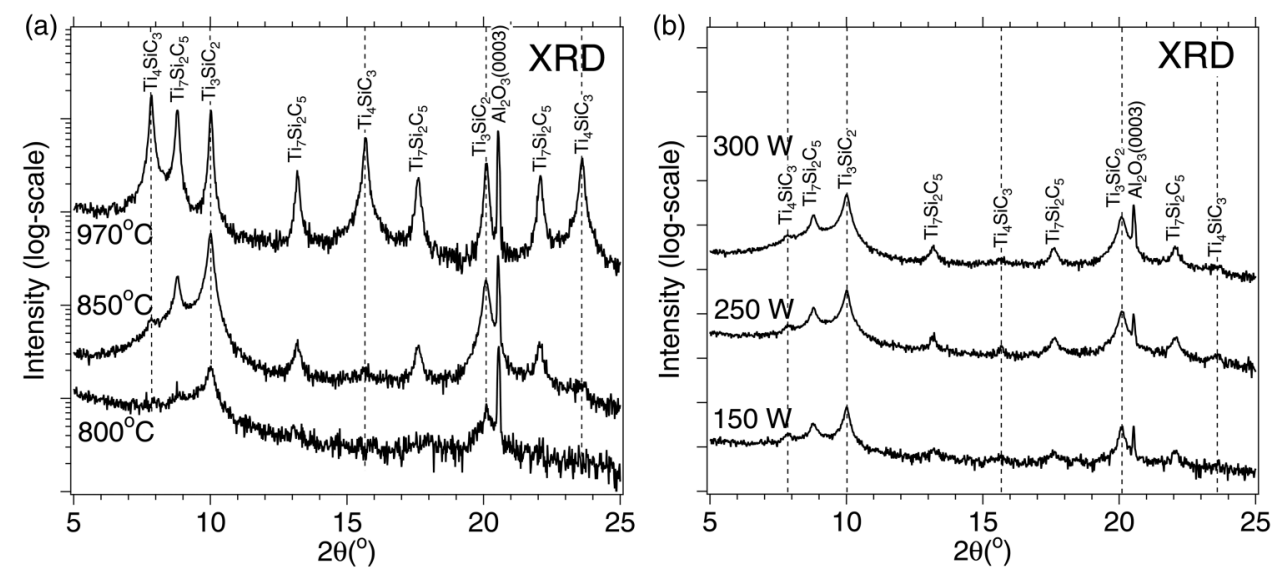

FIG. 5 Diffraction patterns at low diffraction angles for the Ti-Si-C films deposited on $\mathrm{Al}_{2} \mathrm{O}_{3}(0001)$ substrates at temperatures of 800 , 850 , and $970{ }^{\circ} \mathrm{C}$ and at a sputtering power of $300 \mathrm{~W}\left[(\mathrm{a})\right.$, left] and at sputtering powers of 150,250 , and $300 \mathrm{~W}$ at a temperature of $850{ }^{\circ} \mathrm{C}[(\mathrm{b})$, right $]$. 
$\mathrm{Ti}_{4} \mathrm{SiC}_{3}$, and $\mathrm{Ti}_{7} \mathrm{Si}_{2} \mathrm{C}_{5}$, which is most pronounced for the $\mathrm{Ti}_{4} \mathrm{SiC}_{3}$ phase. This agrees with observations showing that growth of $\mathrm{Ti}_{4} \mathrm{SiC}_{3}$ is favored at a temperature of $1000{ }^{\circ} \mathrm{C}^{58}$ From the bottom diffractogram in the right panel of Fig. 4(b), it is seen that a sputtering power of $50 \mathrm{~W}$ at $850^{\circ} \mathrm{C}$ results in growth of 111-oriented TiC. Tripling the sputtering power to $150 \mathrm{~W}$ results in nucleation of $\mathrm{Ti}_{3} \mathrm{SiC}_{2}, \mathrm{Ti}_{4} \mathrm{SiC}_{3}$, and the intergrown $\mathrm{Ti}_{7} \mathrm{Si}_{2} \mathrm{C}_{5}$ structure as observed by the peaks in Fig. 5(b), right panel. The formation of TiC should be favored by a C-rich composition. ${ }^{59}$

Figure 6(a) shows an HRTEM image that illustrates intergrowth of the MAX phases $\mathrm{Ti}_{4} \mathrm{SiC}_{3}, \mathrm{Ti}_{5} \mathrm{Si}_{2} \mathrm{C}_{5}$, and $\mathrm{Ti}_{3} \mathrm{SiC}_{2}$ between $\mathrm{TiC}$ grains. This has previously been observed in Refs. 17 and 18. $\mathrm{The} \mathrm{Ti}_{3} \mathrm{SiC}_{2}, \mathrm{Ti}_{4} \mathrm{SiC}_{3}$, and $\mathrm{Ti}_{7} \mathrm{Si}_{2} \mathrm{C}_{5}$ phases are consistent with the $\theta / 2 \theta$ diffraction patterns in Figs. 4 and 5. An interesting structure consisting of a half unit cell of $\mathrm{Ti}_{3} \mathrm{SiC}_{2}$ together with a half lattice of $\mathrm{Ti}_{5} \mathrm{SiC}_{4}$ that is observed between $\mathrm{Ti}_{7} \mathrm{Si}_{2} \mathrm{C}_{5}$ and $\mathrm{Ti}_{3} \mathrm{SiC}_{2}$, indicating a potential new structure of $\mathrm{Ti}_{8} \mathrm{Si}_{2} \mathrm{C}_{6}$, that appears similar to the $\mathrm{Ti}_{7} \mathrm{Si}_{2} \mathrm{C}_{5}$ structure. The corresponding STEM image gives the epitaxial relationship between the MAX phases and the TiC matrix, that is: (0002)[1 100$] \mathrm{MAX} / /(111)[11 \overline{2}] \mathrm{TiC}$. The MAX phases appear to nucleate and grow inside of the TiC. From HRTEM, we find no MAX-phase nucleation directly formed on the surface of $\mathrm{Al}_{2} \mathrm{O}_{3}$ substrate, which is different from previous studies on $\mathrm{Ti}_{3} \mathrm{AlC}_{2} \cdot{ }^{60-63}$ Instead, TiC is nucleated on the $\mathrm{Al}_{2} \mathrm{O}_{3}$ substrate with an epitaxial relationship of (111)[11 $\overline{2}] \mathrm{TiC} / /(0002)[1 \overline{1} 00] \mathrm{Al}_{2} \mathrm{O}_{3}$ as shown in Fig. 6(b). Twinning of the $\mathrm{TiC}$ is known to favor the nucleation of MAX-phases by forming trigonal prismatic sites for the larger silicon atoms to accommodate in the structure, ${ }^{64}$ which was frequently observed in the film. Twinning often appears as Moire fringes with plane distances of three times of that of the $\mathrm{TiC}(111)$. Here, care was taken to distinguish the MAX-layered structures from the Moire fringes originating from $\mathrm{TiC}(111)$ in the HRTEM images. To verify the variation of the chemical composition in the MAX phases, EDX mapping was carried out and the results are shown in Figs. 6(c)-6(f). The composition was obtained from EDX analysis of the $\mathrm{Ti}_{3} \mathrm{SiC}_{2}$ phase yielded a Ti:Si ratio of about 4:1. Thus, the $\mathrm{Si}$ content is lower than nominal for $\mathrm{Ti}_{3} \mathrm{SiC}_{2}$, which is an indication of possible vacancies in the Si layers.

The formation of an epitaxial TiC "incubation layer" typically occurs for epitaxial growth of MAX phases. High supersaturation of the A element is usually needed before the elements partition to form the MAX phases..$^{17,18,25}$ Furthermore, the TEM micrograph in Fig. 6(a) shows that $\mathrm{TiC}$ is heavily twinned with either $\mathrm{ABC}$ or BCA stacking and where the twining yields a second in-plane relationship of $\mathrm{TiC}[0 \overline{1} 1] / / \mathrm{Al}_{2} \mathrm{O}_{3}[10 \overline{1} 0]$. This has been observed by Palmquist et al. ${ }^{17}$ and Emmerlich et al. ${ }^{18}$ and was explained by $\mathrm{Si}$ lowering the twin-fault energy for $\mathrm{TiC}(111)$.

Figure 7 shows four-point probe resistivity measurements on films deposited on $\mathrm{Al}_{2} \mathrm{O}_{3}(0001)$ substrates using substrate temperatures ranging between $\mathrm{RT}$ and $850^{\circ} \mathrm{C}$ at a sputtering power of $300 \mathrm{~W}$ as well as sputtering powers between 50 and $300 \mathrm{~W}$ at substrate temperatures of $850^{\circ} \mathrm{C}$. As observed, the measured resistivity values are in the range $\sim 120$ to $\sim 450 \mu \Omega \mathrm{cm}$ and with the lowest resistivity in the film deposited at $850^{\circ} \mathrm{C}$, using a sputtering power of $300 \mathrm{~W}$. These values are an order of magnitude higher than measured for epitaxial $\mathrm{Ti}_{3} \mathrm{SiC}_{2}$ films in the region of $20-25 \mu \Omega \mathrm{cm} .{ }^{17} \mathrm{We}$ attribute this to less-conductive TiC inclusions as supported by the TiC peaks of high intensity in the $\theta / 2 \theta$ diffractograms and the low-resolution TEM image in Fig. 6(a); the measured resistivity values for epitaxial $\mathrm{TiC}$ films being in the region of $200-260 \mu \Omega \mathrm{cm}^{17}$

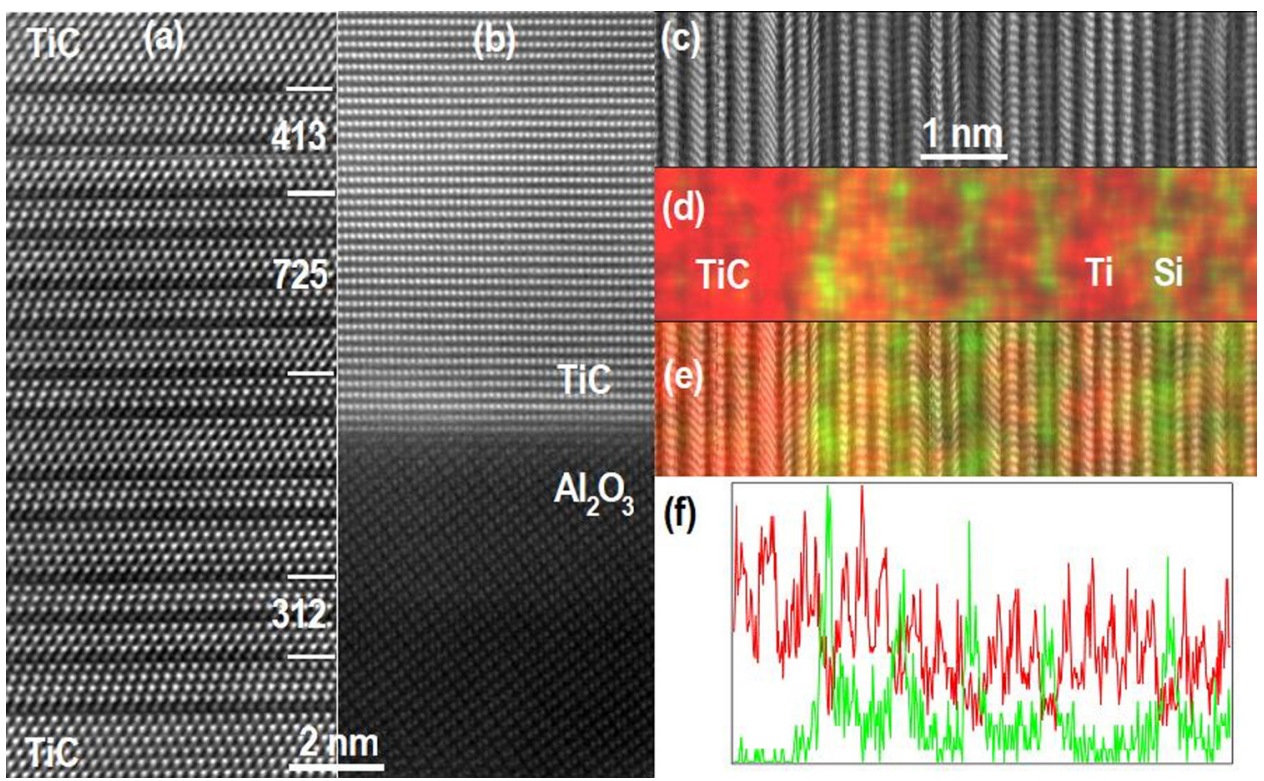

FIg. 6. (a) shows an HRTEM image of MAX phases $\mathrm{Ti}_{3} \mathrm{SiC}_{2}, \mathrm{Ti}_{4} \mathrm{SiC}_{3}$, and $\mathrm{Ti}_{7} \mathrm{Si}_{2} \mathrm{C}_{5}$ embedded in $\mathrm{TiC}$, (b) STEM image of an interface between the TiC film and $\mathrm{Al}_{2} \mathrm{O}_{3}$ substrate, (c) EDX mapping of the STEM image, (d) $\mathrm{Ti}+\mathrm{Si}$ map, where red/darker represents Ti and green/lighter represents $\mathrm{Si}$, (e) the STEM image superimposed with $\mathrm{Ti}+\mathrm{Si}$ map ( $\mathrm{Ti}$ in red/darker and $\mathrm{Si}$ in green/lighter), (f) the corresponding line scan along the 0001 direction (Ti in red/darker and $\mathrm{Si}$ in green/lighter). 


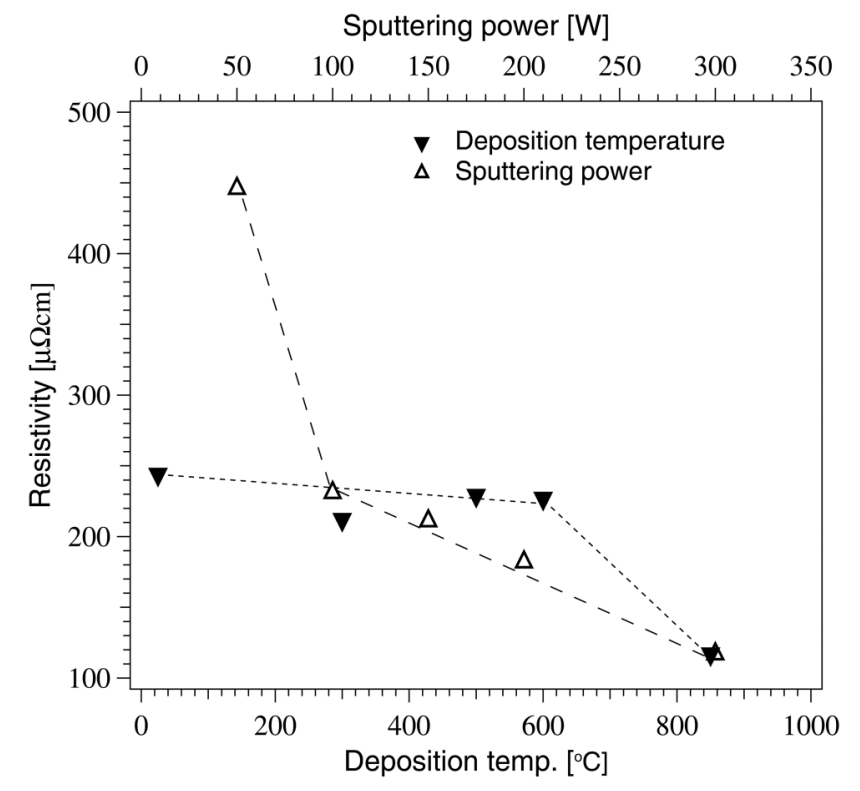

FIG. 7. Four-point probe resistivity of Ti-Si-C films deposited on $\mathrm{Al}_{2} \mathrm{O}_{3}(0001)$ substrates using substrate temperatures of RT, 300, 500, 600, and $850^{\circ} \mathrm{C}$ at a sputtering power of $300 \mathrm{~W}$ as well as sputtering powers of $50,100,150,200$, and $300 \mathrm{~W}$ at a substrate temperature of $850{ }^{\circ} \mathrm{C}$. The dashed lines are trend guides for the eye.

From the ERDA results, it is clear that the stoichiometry of the $\mathrm{Ti}_{3} \mathrm{SiC}_{2}$ compound target is not preserved in the deposited Ti-Si-C films. This stoichiometry difference has been reported before ${ }^{24-27}$ and occurs because of the deposition geometry and difference in angular distribution of the elements, as discussed earlier. The fact that the films are $\mathrm{C}$-rich seems to favor the growth of $\mathrm{TiC}$, which is possibly due to (i) the strong driving force of the metal Ti to form carbides and (ii) the large homogeneity range of the phase, ranging from $\mathrm{TiC}_{0.47}$ to $\mathrm{TiC}_{0.99},{ }^{59}$ to compare with 33 at. $\%$ $\mathrm{Ti}_{3} \mathrm{SiC}_{2}, \sim 35.7$ at. $\% \mathrm{Ti}_{7} \mathrm{Si}_{2} \mathrm{C}_{5}$ and 37.5 at. $\% \mathrm{Ti}_{4} \mathrm{SiC}_{3}$. The diffraction patterns in Fig. 4 indicate from the $2 \theta$ angles of the position of the peaks TiC 111, 222, 333, a C-rich composition for the deposited TiC. ${ }^{54}$ Thus, the excess $\mathrm{C}$ favors to form $\mathrm{TiC}$ instead of the $\mathrm{Ti}_{3} \mathrm{SiC}_{2}, \mathrm{Ti}_{7} \mathrm{Si}_{2} \mathrm{C}_{5}$, and $\mathrm{Ti}_{4} \mathrm{SiC}_{3}$ phases. Growth at high temperature $\geq 850^{\circ} \mathrm{C}$ favors growth of $\mathrm{Ti}_{3} \mathrm{SiC}_{2}, \mathrm{Ti}_{7} \mathrm{Si}_{2} \mathrm{C}_{5}$, and $\mathrm{Ti}_{4} \mathrm{SiC}_{3}$ phases as shown by the $\mathrm{XRD}$ and the TEM. Increasing the temperature to $970{ }^{\circ} \mathrm{C}$ favors the growth of the $\mathrm{Ti}_{4} \mathrm{SiC}_{3}$ phase, with a higher $\mathrm{C}$ content compared to $\mathrm{Ti}_{3} \mathrm{SiC}_{2}$ seen from 37.5 at. $\% \mathrm{C}$ in 413 and 33 at. $\%$ in 312. Interestingly, the $\mathrm{Si}$ content is lower than in $\mathrm{Ti}_{3} \mathrm{SiC}_{2}$ seen from 12.5 at. $\%$ in $\mathrm{Ti}_{4} \mathrm{SiC}_{3}$ and $\sim 16.7$ at. $\%$ in $\mathrm{Ti}_{3} \mathrm{SiC}_{2}$.

This occurs because of the higher vapor pressure of $\mathrm{Si}$ compared to the other elements, resulting in a reduced sticking coefficient of $\mathrm{Si}$. The evaporation of A-elements is a general phenomenon in MAX-phase growth and even more pronounced for elements with higher vapor pressures (e.g., $\mathrm{Al}$ and In). ${ }^{65}$ This implies that growth of $\mathrm{Ti}_{3} \mathrm{SiC}_{2}$ from a compound source is restricted to a certain temperature range to avoid $\mathrm{Si}$ evaporation and the on-set for growth of phases with a lower $\mathrm{Si}$ content such as $\mathrm{Ti}_{4} \mathrm{SiC}_{3}$ and $\mathrm{Ti}_{7} \mathrm{Si}_{2} \mathrm{C}_{5}$ with 12.5 at. $\%$ and 14.3 at. $\% \mathrm{Si}$, respectively.
Our results show the difficulties in depositing singlephase and epitaxial $\mathrm{Ti}_{3} \mathrm{SiC}_{2}$ films from a $\mathrm{Ti}_{3} \mathrm{SiC}_{2}$ compound target. From XRD, we find $\mathrm{TiC}, \mathrm{Ti}_{4} \mathrm{SiC}_{3}$, and $\mathrm{Ti}_{7} \mathrm{Si}_{2} \mathrm{C}_{5}$ as competing phases and where growth of $\mathrm{Ti}_{3} \mathrm{SiC}_{2}$ seems restricted by temperature below $1000{ }^{\circ} \mathrm{C}$. The difficulties in controlling the processes are mainly attributed to the angular dependence of the sputtered species from the target at the applied process conditions. However, the properties determined for the applied $\mathrm{Ti}_{3} \mathrm{SiC}_{2}$ target seen from minority phases and oxygen contaminants set further restrictions on the epitaxial thin film growth. For this, we acknowledge the development of sputtering targets with improved properties as exemplified for growth of $\mathrm{Ti}_{2} \mathrm{AlC}$ (Refs. 66 and 67) and $\mathrm{Ti}_{2} \mathrm{AlN},{ }^{68,69}$ respectively.

\section{CONCLUSIONS}

From magnetron sputter deposition of a $\mathrm{Ti}_{3} \mathrm{SiC}_{2}$ compound target, we show that epitaxial $\mathrm{TiC}, \mathrm{Ti}_{3} \mathrm{SiC}_{2}, \mathrm{Ti}_{4} \mathrm{SiC}_{3}$, and $\mathrm{Ti}_{7} \mathrm{Si}_{2} \mathrm{C}_{5}$ can be deposited from a $\mathrm{Ti}_{3} \mathrm{SiC}_{2}$ compound target at temperatures of $850{ }^{\circ} \mathrm{C}$ and above. Higher sputtering powers applied to the target favor epitaxial growth of $\mathrm{Ti}_{\mathrm{n}+1} \mathrm{SiC}_{\mathrm{n}}$ phases and yield films of lower resistivity values. The composition of the grown films has a higher carbon content than in the $\mathrm{Ti}_{3} \mathrm{SiC}_{2}$ phase due to differences in the angular distribution of $\mathrm{C}, \mathrm{Si}$, and $\mathrm{Ti}$ during sputtering. XRD of the $\mathrm{Ti}_{3} \mathrm{SiC}_{2}$ compound target shows that it contains $\mathrm{TiC}$ and $\mathrm{TiSi}_{2}$ as minority phases as well as $\sim 8$ at. $\% \mathrm{O}$ according to XPS. Thus, growth of epitaxial singe-phase $\mathrm{Ti}_{3} \mathrm{SiC}_{2}$ films requires a growth flux with strict $3 \mathrm{Ti}: \mathrm{Si}: 2 \mathrm{C}$ composition as well as a temperature in the region of $800{ }^{\circ} \mathrm{C}$.

\section{ACKNOWLEDGMENTS}

The authors acknowledge funding from the Swedish Government Strategic Research Area in Materials Science on Functional Materials at Linköping University (Faculty Grant SFO-Mat-LiU No. 2009-00971). M.M. acknowledges financial support from the Swedish Energy Research (No. 43606-1) and the Carl Tryggers Foundation (Nos. CTS16:303 and CTS14:310). P.E. acknowledges the Knut and Alice Wallenberg Foundation through the Wallenberg Academy Fellows program. G.G. acknowledges financial support from the Åforsk Foundation (Grant No. 16-359) and Carl Tryggers Foundation (No. CTS 17:166). The authors acknowledge Åke Öberg at ABB Sverige AB for the target material and Uppsala University for access to the Tandem Laboratory.

\footnotetext{
${ }^{1}$ M. W. Barsoum, Prog. Solid State Chem. 28, 201 (2000).

${ }^{2}$ M. W. Barsoum, MAX Phases: Properties of Machinable Ternary Carbides and Nitrides (Wiley-VCH, Verlag $\mathrm{GmbH} \&$ Co. KGaA, Weinheim, Germany, 2013).

${ }^{3}$ P. Eklund, M. Beckers, U. Jansson, H. Högberg, and L. Hultman, Thin Solid Films 518, 1851 (2010).

${ }^{4}$ M. W. Barsoum and M. Radovic, Ann. Rev. Mater. Res. 41, 195 (2011).

${ }^{5}$ M. Radovic and M. W. Barsoum, Am. Ceram. Soc. Bull. 92, 20 (2013).

${ }^{6}$ Z. M. Sun, Int. Mater. Rev. 56, 143 (2011).

${ }^{7}$ W. Jeitschko and H. Nowotny, Monatsh. Chem. 98, 329 (1967).

${ }^{8}$ M. Magnuson and M. Mattesini, Thin Solid Films 621, 108 (2017).
} 
${ }^{9}$ P. Eklund, J. Rosen, and P. O. Å. Persson, J. Phys. D Appl. Phys. 50, 113001 (2017).

${ }^{10}$ J. J. Nickl, K. K. Schweitzer, and P. Luxenberg, J. Less Comm. Met. 26, 335 (1972).

${ }^{11}$ T. Goto and T. Hirai, Mater. Res. Bull. 22, 1195 (1987).

${ }^{12}$ C. Racault, F. Langlais, and C. C. Bernard, J. Mater. Sci. 29, 5023 (1994).

${ }^{13}$ E. Pickering, W. J. Lackey, and S. Crain, Chem. Vap. Deposition 6, 289 (2000).

${ }^{14}$ S. Jacques, H. Fakih, and J.-C. Viala, Thin Solid Films 518, 5071 (2010).

${ }^{15}$ S. A. Kinnunen, J. Malm, K. Arstila, M. Lahtinen, and T. Sajavaara, Nucl. Instrum. Methods Phys. Res. Sect. B 406, 152 (2017).

${ }^{16}$ J.-P. Palmquist, U. Jansson, T. Seppänen, P. O. A. Persson, J. Birch, L. Hultman, and P. Isberg, Appl. Phys. Lett. 81, 835 (2002).

${ }^{17}$ J.-P. Palmquist et al., Phys. Rev. B 70, 165401 (2004).

${ }^{18}$ J. Emmerlich, J.-P. Palmquist, H. Högberg, J. M. Molina-Aldareguia, Z. Czigány, S. Sasvári, P. O. Å. Persson, U. Jansson, and L. Hultman, J. Appl. Phys. 96, 4817 (2004).

${ }^{19}$ B. Holm, R. R. Ahuja, S. Li, and B. Johansson, J. Appl. Phys. 91, 9874 (2002).

${ }^{20}$ T. H. Scabarozi, J. D. Hettinger, S. E. Lofland, J. Lu, L. Hultman, J. Jensen, and P. Eklund, Scr. Mater. 65, 811 (2011).

${ }^{21}$ P. V. Istomin, E. I. Istomina, A. Nadutkin, V. E. Grass, and M. Presniakov, Inorg. Chem. 55, 11050 (2016).

${ }^{22}$ P. V. Istomin, E. I. Istomina, A. Nadutkina, V. E. Grass, A. Leonov, M. Kaplan, and M. Presniakov, Ceram. Int. 43, 16128 (2017).

${ }^{23}$ E. I. Istomina, P. V. Istomin, A. V. Nadutkin, V. E. Grass, and A. S. Bogdanova, Inorg. Mater. 54, 528 (2018).

${ }^{24}$ P. Eklund, J. Emmerlich, H. Högberg, O. Wilhelmsson, P. Isberg, J. Birch, P. O. Å. Persson, U. Jansson, and L. Hultman, J. Vac. Sci. Technol. B 23, 6 (2005).

${ }^{25}$ P. Eklund, M. Beckers, J. Frodelius, H. Högberg, and L. Hultman, J. Vac. Sci. Technol. A 25, 1381 (2007).

${ }^{26}$ M. Balzer and M. Fenker, see http://www.fem-online.de/balzer_ stoichiometry_ti3sic2_hipims.pdf.

${ }^{27}$ J. Alami, P. Eklund, J. Emmerlich, O. Wilhelmsson, U. Jansson, H. Högberg, L. Hultman, and U. Helmersson, Thin Solid Films 515, 1731 (2006).

${ }^{28}$ H. Nowotny, Prog. Solid State Chem. 2, 27 (1970).

${ }^{29}$ V. Vishnyakov, J. Lu, P. Eklund, L. Hultman, and J. Colligon, Vacuum 93, 56 (2013).

${ }^{30}$ A. G. Dirks, R. A. M. Wolters, and A. J. M. Nellissen, Thin Solid Films 193-194, 201 (1990).

${ }^{31}$ D. B. Bergstrom, F. Tian, I. Petrov, J. Moser, and J. E. Greene, Appl. Phys. Lett. 67, 3102 (1995).

${ }^{32}$ L. R. Shaginyan, M. Mišina, S. Kadlec, L. Jastrabík, A. Macková, and V. Peřina, J. Vac. Sci. Technol. A 19, 2554 (2001).

${ }^{33}$ J. Neidhardt, S. Mráz, J. M. Schneider, E. Strub, W. Bohne, B. Liedke, W. Möller, and C. Mitterer, J. Appl. Phys. 104, 063304 (2008).

${ }^{34}$ P. Eklund, C. Virojanadara, J. Emmerlich, L. I. Johansson, H. Högberg, and L. Hultman, Phys. Rev. B 74, 045417 (2006).

${ }^{35}$ G. Greczynski, D. Primetzhofer, and L. Hultman, Appl. Surf. Sci. 436, 102 (2018).

${ }^{36}$ CASA XPS, v.2.3.19, see http://www.casaxps.com/.

${ }^{37}$ H. J. Whitlow, G. Possnert, and C. S. Petersson, Nucl. Instrum. Methods Phys. Res. Sect. B 27, 448 (1987).

${ }^{38}$ J. Jensen, D. Martin, A. Surpi, and T. Kubart, Nucl. Instrum. Methods Phys. Res. Sect. B 268, 1893 (2010).
${ }^{39} \mathrm{M}$. S. Janson, CONTES (Conversion of Time-Energy Spectra)—A Program for ERDA Data Analysis (2004).

${ }^{40}$ T. Degen, M. Sadki, E. Bron, U. König, and G. Nénert, Powder Diffr. 29, S13 (2014).

${ }^{41}$ J. Lu, X. D. Gao, S. L. Zhang, and L. Hultman, Cryst. Growth Design 13, 1801 (2013).

${ }^{42}$ J. M. Schneider, D. P. Sigumonrong, D. Music, C. Walter, J. Emmerlich, R. Iskandar, and J. Mayer, Scr. Mater. 57, 1137 (2007).

${ }^{43}$ S. E. Stoltz, H. I. Starnberg, and M. W. Barsoum, J. Phys. Chem. Solids 64, 2321 (2003).

${ }^{44}$ O. Wilhelmsson et al., J. Cryst. Growth 291, 290 (2006).

${ }^{45}$ J. F. Moulder, W. F. Stickle, S. P. E. and K. D. Bomben, Handbook of $X$-ray Photoelectron Spectroscopy—A Reference Book of Standard Spectra for Indentification and Interpretation of XPS Data (Perkin-Elmer, Eden Prairie, 1992).

${ }^{46}$ M. Magnuson et al., Phys. Rev. B 72, 245101 (2005).

${ }^{47}$ C. Chen, C. Huang, Y. Lin, L. Chen, and K. Chen, Diam. Relat. Mater. 14, 1126 (2005).

${ }^{48}$ M. Magnuson, E. Lewin, L. Hultman, and U. Jansson, Phys. Rev. B 80, 235108 (2009).

${ }^{49}$ E. Lewin et al., Surf. Coat. Technol. 202, 3563 (2008).

${ }^{50}$ E. Lewin, M. Gorgoi, F. Schäfers, S. Svensson, and U. Jansson, Surf. Coat. Technol. 204, 445 (2009).

${ }^{51}$ L. Muehlhoff, W. J. Choyke, M. J. Bozack, and J. J. T. Yates, J. Appl. Phys. 60, 2842 (1986).

${ }^{52}$ A. Mesarwi and A. Ignatiev, Surf. Sci. 244, 15 (1991).

${ }^{53}$ International Centre for Diffraction Data, $\mathrm{Ti}_{3} \mathrm{SiC}_{2}$, PDF No. 74-0310.

${ }^{54}$ International Centre for Diffraction Data, TiC, PDF No. 32-1383.

${ }^{55}$ International Centre for Diffraction Data, $\mathrm{TiSi}_{2}$, PDF No. 85-0879.

${ }^{56} \mathrm{C}$. Walter, C. Martinez, T. EI-Raghy, and J. M. Schneider, Steel Res. Int. 76, 225 (2005).

${ }^{57}$ M. Magnuson et al., Phys. Rev. B. 74, 205102 (2006).

${ }^{58}$ H. Högberg, L. Hultman, J. Emmerlich, T. Joelsson, P. Eklund, J. M. Molina-Aldaregui, J.-P. Palmquist, O. Wilhelmsson, and U. Jansson, Surf. Coat. Technol. 193, 6 (2005).

${ }^{59}$ H. O. Pierson, Handbook of Refractory Carbides and Nitrides Properties, Characteristics, Processing and Applications (Noyes, Atlantic City, NJ, 1996).

${ }^{60}$ J. Frodelius, P. Eklund, M. Beckers, P. O. Å. Persson, H. Högberg, and L. Hultman, Thin Solid Films 518, 1621 (2010).

${ }^{61}$ J. Frodelius, J. Lu, J. Jensen, P. Paul, L. Hultman, and P. Eklund, J. Eur. Ceram. Soc. 33, 375 (2013).

${ }^{62}$ M. D. Tucker, P. O. Å. Persson, M. C. Guenette, J. Rosén, M. M. M. Bilek, and D. R. McKenzie, J. Appl. Phys. 109, 014903 (2011).

${ }^{63}$ M. C. Guenette, M. D. Tucker, M. Ionescu, M. M. M. Bilek, and D. R. McKenzie, J. Appl. Phys. 109, 083503 (2011).

${ }^{64}$ R. Yu, Q. Zhan, L. L. He, Y. C. Zhou, and H. Q. Ye, Acta Mater. 50, 4127 (2002).

${ }^{65}$ H. Rueß, M. Baben, S. Mráz, L. Shang, P. Polcik, S. Kolozsvári, M. Hans, D. Primetzhofer, and J. M. Schneider, Vacuum 145, 285 (2017).

${ }^{66}$ Y. Li, G. Zhao, Y. Qian, J. Xu, and M. Li, Vacuum 153, 62 (2018).

${ }^{67}$ M. Magnuson et al., Phys. Rev. B. 74, 195108 (2006).

${ }^{68}$ Y. Li, G. Zhao, H. Qi, M. Li, Y. Zheng, Y. Qian, and L. Sheng, Ceram. Int. 44, 17530 (2018).

${ }^{69}$ M. Magnuson et al., Phys. Rev. B. 76, 195127 (2007). 